\title{
Water hardness and the effects of Cd on oxygen consumption, plasma chlorides and bioaccumulation in Tilapia sparrmanii
}

\author{
WJ van Aardt*, and J Booysen \\ School of Environmental Science and Development, Private Bag X6001, Potchefstroom University, Potchefstroom, South Africa
}

\begin{abstract}
Closed system respirometry was performed on captive juvenile ( $30 \pm 8 \mathrm{~g}$; mean \pm S.E.M) Tilapia sparrmanii exposed for $96 \mathrm{~h}$ to low $\left(1 \mathrm{mg} \cdot \ell^{-1}\right)$ and high $\left(20 \mathrm{mg} \cdot \ell^{-1}\right)$ levels of cadmium in soft and hard water. In hard water $\left(235 \mathrm{mg} \cdot \ell^{-1}\right.$ as $\left.\mathrm{CaCO}_{3}\right)$, cadmium $(\mathrm{Cd})$ applied as $\mathrm{CdCl}_{2}$, precipitates completely out but in very soft water $\left(16.5 \mathrm{mg} \cdot \ell^{-1}\right.$ as $\left.\mathrm{Ca}^{-} \mathrm{CO}_{3}\right), 23 \%$ of $\mathrm{Cd}$ is in solution $96 \mathrm{~h}$ after it was dissolved. Cadmium complexation is not caused by the presence of chlorides but probably depends on carbonates and sulphates present in Mooi River water. Handling stress, that lasts for at least $6 \mathrm{~h}$, increased the specific oxygen consumption rate of T. sparrmanii $\left(\mathrm{MO}_{2}\right)$ by more than $30 \%$ compared to resting oxygen consumption levels. In hard water no change in the $\mathrm{M}_{2}$ was found when $T$. sparrmanii was exposed to $1,5,10$, or $20 \mathrm{mg}$ of $C d \cdot \ell^{-1}$ of water. In soft alkaline water all fish died when exposed for $96 \mathrm{~h}$ in $20 \mathrm{mg} \mathrm{Cd} \cdot \ell^{-1}$. For $10 \mathrm{mg} \mathrm{Cd} \cdot \ell^{-1}$, the $\mathrm{MO}_{2}$ was reduced significantly $(\mathrm{p}<0.05)$ by $30 \%$. The percentage cadmium dissolved in hard water was, after $96 \mathrm{~h}$, below $1 \%, 96 \mathrm{~h}$ after it had been dissolved. About $2000 \mu \mathrm{g} \mathrm{Cd} \cdot \mathrm{g}^{-1}$ accumulates per gram dried gill mass when fish are exposed to $20 \mathrm{mg} \mathrm{Cd} \cdot \ell^{-1}$ in hard water. For soft water the $\mathrm{Cd}$ accumulation is about twice as much. In liver tissue more than $60 \mu \mathrm{g} \mathrm{Cd}$ accumulates per gram dried liver mass in hard water. In soft water the accumulation was three times as much. Blood plasma chlorides decreased from a mean of $130 \mathrm{mmol}$ to $60 \mathrm{mmol}$ when exposed to $20 \mathrm{mg} \mathrm{Cd} \cdot \ell^{-1}$ in soft water. The differences were statistically significant $(\mathrm{P}<0.05)$. No decrease in blood plasma chlorides was found in hard water when fish were exposed to $20 \mathrm{mg} \mathrm{Cd} \cdot \ell^{-1}$ of water. Fish handling reduces the oxygen consumption rate by $35 \%$ but $\mathrm{MO}_{2}$ returns to normal resting levels 6 $\mathrm{h}$ after handling stress. It is concluded from the results that $\mathrm{M}_{2}$ and blood chlorides can be used as parameters for $\mathrm{Cd}$ toxicity in a $96 \mathrm{~h}$ exposure period provided that the precipitation of $\mathrm{Cd}$ in the water is known and the $\mathrm{pH}$ of the water is monitored.
\end{abstract}

Keywords: fish, $\mathrm{Cd}, \dot{\mathrm{MO}}{ }_{2}$, body electrolytes, hard water, soft water

\section{Introduction}

The introduction of toxic metals such as Cd into the environment by anthropogenic sources is an important challenge to toxicologists and ecological management. The concentration of the metal, its geographical transportation, exposure to a target organism and the responses of the individual organism to a specific toxic metal should be known (Truhaut, 1974; Carpené et al., 1990). The peltic sediments adjacent to the gold mine slimes dams near Carletonville, South Africa, have Cd concentrations of between 0.18 and 0.86 $\mu \mathrm{g} \cdot \mathrm{g}^{-1}$ with an enrichment factor of 3 compared with standard South shale. These determinations were made before 1977 (Wittmann and Förstner, 1977). Since then no physical changes of the mine drainage around the slimes dams have taken place. A tributary of the Mooi River, receiving dolomitic water (Midgley et al., 1990), but no drainage from the peltic sediments, from the mines, drains into the upper reaches of the Mooi River. It has been estimated that the global input of $9400 \mathrm{t}$ of Cd into the aquatic ecosytems per year is caused by anthropogenic activities where mining, smelting and refining contributes $41.5 \%$ of the total input (Nriagu and Pacyna, 1988).

Nothing is known what the effect of $\mathrm{Cd}$ is on the oxygen consumption rate of South African fishes. It has been shown that exposure of cadmium to fish affects the kidney and liver functions (Friberg et al., 1979). The use of gill ventilation, respiration or

\footnotetext{
* To whom all correspondence should be addressed.

용 +2718 299 2511; fax: +2718 299 2503;

e-mail: drkwjva@puknet.puk.ac.za

Received 19 November 2002; accepted in revised form 22 October 2003.
}

metabolic rate for individual fish to measure the responses of fish to toxic metals has been poorly studied (Anderson and D' Apollina, 1978; Kelly, 1988; Rand et al., 1995). According to Depledge (1990) individual physiological variability can be used as a tool to investigate toxicity effects above traditional methods such $\mathrm{LC}_{50}$ values especially for aquatic organisms. In this regard he strongly advocates the use of respiratory responses to pollutants. Furthermore, Klerks and Levinton (1989) have demonstrated that selection pressure has resulted in the evolution of resistance to $\mathrm{Cd}$ in an aquatic oligocheate.

Gill epithelial damage by metal toxicants in fish is often characterised by excessive excretion of mucus (Mallatt, 1985). Heath (1984), Felts and Heath (1984) and Heath (1987), working on the fish Lepomis macrochirus, disputed the view put forward by Burton et al. (1972), that heavy metals cause only tissue hypoxia due to excessive secretion of mucus on the gill surfaces. They provided evidence that heavy metals acted on the gill physiology, resulting in a decrease in the oxygen consumption because of ionregulatory and acid-base balance disturbances (Goss and Wood, 1988).

An increase in the oxygen consumption rates by heavy metals has been described, effected by the stressor responses in fish. (Schreck and Lorz, 1978; Wendelaar-Bonga, 1997). These stressor responses induce a dramatic increase in adrenaline, resulting in increased oxygen uptake rate, initiated by higher gill ventilation rates. Furthermore, stimulation of the branchial blood flow and branchial oxygen diffusion capacity is enhanced. Most of these actions are caused by cathechol-amines acting through adrenergic mechanisms (Wendelaar-Bonga, 1997; Pelgrom et al., 1994). It is 


\begin{tabular}{|c|c|c|c|c|c|c|c|}
\hline \multicolumn{8}{|c|}{$\begin{array}{l}\text { TABLE } 1 \\
\text { Chemical composition and water quality from three Mooi River water types, Rooipoort } \\
\text { borehole water and reconstituted water }{ }^{+} \text {(Rand et al. (1995). VS*, very soft water; HW*, } \\
\text { hard water; VH*, very hard water; n a, not analysed }\end{array}$} \\
\hline & $\begin{array}{l}\text { Mooi } \\
\text { River }\end{array}$ & $\begin{array}{l}\text { Fish } \\
\text { tank }\end{array}$ & $\begin{array}{l}\text { Tap } \\
\text { water }\end{array}$ & $\begin{array}{c}\text { Rooipoort } \\
\text { borehole }\end{array}$ & VS $^{+*}$ & $\mathrm{HW}^{+*}$ & $\mathbf{V H}^{+*}$ \\
\hline Electrical conductivity $\left(\mu \mathrm{S} . \mathrm{cm}^{-1}\right)$ & 680 & 840 & 660 & 110 & 179 & 569 & 937 \\
\hline $\mathrm{pH}\left(-\log \mathrm{H}^{+}\right.$conc. $)$ & 8.19 & 8.14 & 8.70 & 7.21 & 8.23 & 8.69 & 8.76 \\
\hline Calcium $\left(\mathrm{mg} \cdot \ell^{-1}\right)$ & 61 & 67 & 61 & 5 & 2.2 & 35.3 & 70.6 \\
\hline $\operatorname{Magnesium}\left(\mathrm{mg} \cdot \ell^{-1}\right)$ & 41 & 50 & 42 & 8 & 3.9 & 63.9 & 127.9 \\
\hline Potassium $\left(\mathrm{mg} \cdot \ell^{-1}\right)$ & 2 & 4 & 2 & $>1$ & 0.2 & 4.1 & 8.3 \\
\hline Chloride $\left(\mathrm{mg} \cdot \ell^{-1}\right)$ & 27 & 36 & 28 & 5 & 0.23 & 3.80 & 7.60 \\
\hline $\operatorname{Sodium}\left(\mathrm{mg} \cdot \ell^{-1}\right)$ & 21 & 28 & 22 & 5 & 3.2 & 52.5 & 105.0 \\
\hline Sulphates $\left(\mathrm{mg} \cdot \ell^{-1}\right)$ & 76 & 115 & 80 & 0.5 & 11.2 & 180 & 360.8 \\
\hline Total alkalinity as $\mathrm{CaCO}_{3}\left(\mathrm{mg} \cdot \ell^{-1}\right)$ & 230 & 252 & 223 & 23 & 16.5 & 115 & 235 \\
\hline$\%$ Cadmium in solution after $96 \mathrm{~h}$ & $\mathrm{n} \mathrm{a}$ & $>1 \%$ & $\mathrm{na}$ & $23 \%$ & $23 \%$ & $1 \%$ & $>1 \%$ \\
\hline
\end{tabular}

therefore surprising that in extensive reviews (Butler, 1978; Anderson \& Conning, 1993; Rand et al., 1995) most of these researchers do not explicitly mention the use of oxygen uptake rates by fish gills as an index or biomarker in toxicity studies on metals. Because of the fish gill's large epithelial surface for gas exchange and its role in water and ion regulation, fish gills may act as a physiological index organ if damaged by toxic metals. Heath (1987) strongly propagates the use of respiratory gas exchange organs as a means to indicate the degree of toxic metal damage. This apparent neglect of using oxygen consumption rates on metal toxicology studies is difficult to explain. It is possible that $\dot{\mathrm{M}} \mathrm{O}_{2}$ measurements used in basic animal physiology (Bridges and Butler, 1989) are not well known or properly applied to experimental toxicology (Anderson and Conning, 1993).

The dolomitic nature of the area draining the Mooi River basin, results in hard water with total alkalinity of more than $230 \mathrm{mg} \cdot \ell^{-1}$ as $\mathrm{CaCO}_{3}$ and an electrical conductivity between 557 and 680 $\mu \mathrm{S} \cdot \mathrm{cm}^{-1}$ (Table 1). It is known (Rand et al., 1995) that heavy metals such as cadmium and lead undergo a precipitation process in hard water where the metal ion and various ligands join chemically to form a new chemical complex (Zitko and Carson, 1976). These complexation reactions result in insoluble precipitates (Kotrly and Sucha, 1985). Nothing is known of the toxicity of high levels of cadmium complexation compounds, caused by hard water, on the biology of fish.

Tilapia sparrmanii is widely distributed south of the Congo basin, occurring both in rivers and lakes and also in temperate regions in South Africa. It is a hardy omnivorous fish that is well adapted to high $\left(32^{\circ} \mathrm{C}\right)$ as well as low $\left(10^{\circ} \mathrm{C}\right)$ temperatures and also to a variety of habitats (Skelton, 1993).

The aim of the present study is to make a contribution as to whether mass specific oxygen consumption rates, and body electrolyte changes, measured in T. sparrmanii, can be used to evaluate the short-term ( $96 \mathrm{~h}$ ) biological effects of cadmium. Particular attention was given to the effects of hard and soft water on the toxicity of complexation compounds of cadmium to $T$. sparrmanii

\section{Materials and methods}

\section{Experimental fish and the fish-keeping plant}

Juvenile Tilapia sparrmanii (A. Smith, 1841) $(30 \pm 8$ g) were netted at Boskop Dam (S.26. 31' 531' and E.27. 07' 348”) using cast nets. Approximately 200 fish per catch were transported for $13 \mathrm{~km}$ to the laboratory in a $400 \ell$ container filled with aerated dam water. Six kilograms of table salt were dissolved in the $400 \ell$ dam water to eliminate Saprolegnia parasitica infection (Walsh, 1984). At the fish plant the fish were exposed in water containing $2 \%$ formaldehyde and $33 \mathrm{mg} \cdot \ell^{-1}$ malachite green for $10 \mathrm{~s}$. After treatment the batch, with a specimen density of 16 fish $\cdot \ell^{-1}$, was placed in aerated $5000 \ell$ fish holding tanks. Each holding tank was thermostatically controlled at a temperature of $20^{\circ} \mathrm{C} \pm 0.5^{\circ} \mathrm{C}$ and formed part of a closed circulating water system consisting of a $1000 \ell$ sedimentation tank and a biological filter tank of $1000 \ell$ capacity.

A submersible pump (Little Giant, Type 6E-CIA-SFS, USA) was placed inside the biological filter tank to maintain a water turnover rate in the system of $3000 \ell \cdot h^{-1}$.

The water inside the fish tank was made to circulate by pumping water at an angle into the tank. In this manner the centrally placed perforated drain pipe collects faeces and left-over food in the fish tank to be deposited in the sedimentation tank. Tanks were made of polypropylene and piping from $40 \mathrm{~mm}$ diameter polyvinyl chloride. Every week the biological filter tank as well as the sedimentation and holding tanks were recharged with 33\% fresh tap water after it was cleaned from remaining food and faeces by suction. High-protein food (Koi-fish pellets, Rainbow, Johannesburg, RSA) was given three times per week. Under these conditions T. sparrmanii thrived, gained body mass and no deaths occurred after the initial $2 \mathrm{~d}$ recovery period. Fish were kept for at least three weeks in the holding tanks before starting the experiments.

\section{Water analysis}

Samples from Mooi River water, used in the fish tanks for exposing the fish to cadmium, were analysed for total hardness, sodium, potassium, magnesium, calcium, sulphates, electrical conductivity, and $\mathrm{pH}$ at $25^{\circ} \mathrm{C}$. Furthermore, water samples from the fish tanks, tap water and from a borehole at the farm Rooipoort 29 (26 $35^{\prime} 882^{\prime \prime}$ and $\left.26^{\circ} 50^{\prime} 348^{\prime \prime}\right)$, were analysed by Midvaal Water Co. (accredited laboratory, number T0132) and presented in Table 1. Reconstituted freshwater (Rand et al., 1995) presenting very soft, hard and very hard water (all above $\mathrm{pH}$ 8.0) was made up in $2 \ell$ containers. The amount of $\mathrm{Cd}$ precipitated in the $2 \ell$ containers from $1 \mathrm{mg} \mathrm{Cd} \cdot \ell^{-1}$ was determined after $96 \mathrm{~h}$ and after vigorous aeration. 


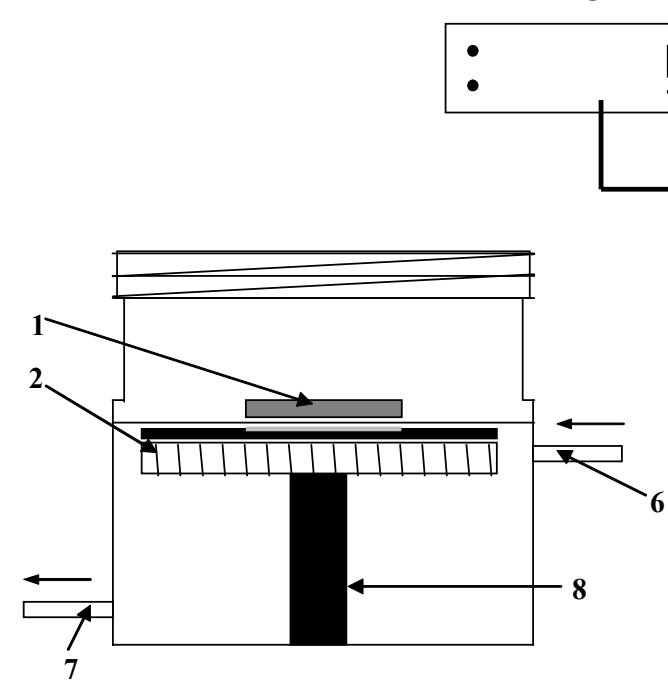

A

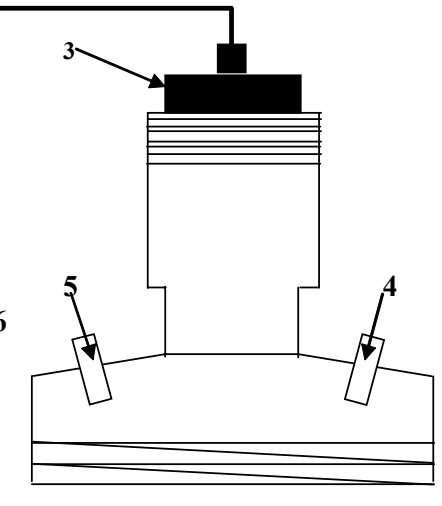

B
During the exposure experiments to $1,5,10$ and $20 \mathrm{mg} \mathrm{Cd} \cdot \ell^{-1}$, the water was vigorously agitated by aeration to constant oxygen saturation levels, because decreased oxygen content in the water increases the toxicity of heavy metals to fish (Lloyd, 1961a).

\section{Closed system respirometry}

The respirometers were made of $130 \mathrm{~mm}$ diameter PVC-tubing provided with two water-tight screw-on lids and two removable perforated PVC lids at the open ends. At opposite sides, along the tube, two Perspex windows were installed to be able to observe the fish and count operculum frequency. The respirometers were suspended in the $1000 \cdot \ell^{-1}$ exposure tanks. Single fish were kept inside the respirometers during the $10 \mathrm{~h}$ recovery period from handling stress, with the two screw-on lids removed but the two perforated lids in place.

\section{Oxygen consumption rate $\left(\mathrm{MO}_{2}\right)$ measurements in normoxic $\left(\mathrm{PO}_{2}: 130 \mathrm{~mm} \mathrm{Hg}\right)$ water}

To operate the 1.180 respirometer, a $50 \mathrm{~m} \ell$ water sample was taken from inside the respirometer ( $\operatorname{start} \mathrm{PO}_{2}$ ), followed (after a respiration period of about $20 \mathrm{~min}$.) by a $50 \mathrm{~m} \ell$ water sample (end $\mathrm{PO}_{2}$ ) when the lid was again opened. Usually the initial $\mathrm{PO}_{2}$ was measured at $130 \mathrm{~mm} \mathrm{Hg}$ and the respiration time and $\mathrm{PO}_{2}$ were noted when the end $\mathrm{PO}_{2}$ decreased to $80 \mathrm{~mm} \mathrm{Hg}$.

\section{Oxygen consumption rate $\left(\mathrm{MO}_{2}\right)$ measurements in progressive hypoxic ( $\mathrm{PO}_{2}$ : 130 to $20 \mathrm{~mm} \mathrm{Hg}$ ) water}

Respirometers $(0.75 \ell$ capacity) were used to measure the time needed by Cd-exposed banded tilapia individuals to deplete the sealed-off water from oxygen. After the $96 \mathrm{~h} \mathrm{Cd}$ exposure period, fish were individually placed inside the respirometers and the lid closed. The specific oxygen consumption rate $\left(\dot{\mathrm{MO}}_{2}\right)$ was calculated from start $(130 \mathrm{~mm} \mathrm{Hg})$ and end $\mathrm{PO}_{2}$ values. The end $\mathrm{PO}_{2}$ of the water was measured from a $50 \mathrm{~m} \ell$ sample after $90 \mathrm{~min}$ when the oxygen partial pressure was usually below $20 \mathrm{~mm} \mathrm{Hg}$.

\section{The $\mathrm{PO}_{2}$ measuring cell}

The temperature-controlled $\left(20^{\circ} \mathrm{C}\left( \pm 0.1^{\circ} \mathrm{C}\right)\right.$ cell used to determine start and end $\mathrm{PO}_{2}$ for the respirometers, is made from Perspex, with a water capacity of $45 \mathrm{~m} \ell$ (Fig. 1) and houses the oxygen electrode. The cell has two $3 \mathrm{~mm}$ diameter ports (Van Aardt and Frey, 1979).

\section{Figure 1}

The $\mathrm{PO}_{2}$ measuring cell $(50 \mathrm{~m} \ell$ capacity), made from Perspex, to measure start and end $\mathrm{PO}_{2}$ values. $A$, Perspex chamber; B, Perspex-head housing the Radiometer oxygen elektrode; $C$, Oxygen meter; The $B$ part of the cell is screwed on part A. 1 magnetic stirrer; 2, water turbine; 3, Clark-polarographic oxygen electrode (Radiometer); 4, inlet for water sample; 5 , outlet for water sample; 6 , water inlet and, 7, water outlet for turbine; 8, axle. Scale, $1: 1 \mathrm{~cm}$.

Water samples $(50 \mathrm{~m} \ell)$ from the respirometers, to be analysed for $\mathrm{PO}_{2}$, were gently injected into the measuring cell through one of the ports. The test water in the cell was constantly stirred by a waterdriven turbine. The time taken to measure the $\mathrm{PO}_{2}$ of a $50 \mathrm{~m} \ell$ test water sample from the respirometers was between 2 and $4 \mathrm{~min}$. A polarographic $\mathrm{PO}_{2}^{-}$electrode, provided with a $20 \mu \mathrm{m}$ diameter platinum cathode from Radiometer, Copenhagen (Model E5046) was used. The $\mathrm{PO}_{2}$ depletion rate of the test water by the cathode at $25^{\circ} \mathrm{C}$ was negligible, e.g. $0.035 \mathrm{~mm} \mathrm{Hg} \cdot \mathrm{min}^{-1}$ when a Teflon membrane of $0.01 \mathrm{~mm}$ thickness was used (Severingshause and Bradley, 1971). The $\mathrm{PO}_{2}$ electrode was calibrated and the membrane changed after every three days according to Hitchman (1983).

\section{$\dot{\mathrm{MO}}_{2}$ measurements in hard or in soft water at $\mathrm{pH} \mathbf{8 . 3 4}$}

Per experiment 25 fish were exposed to four different concentrations of cadmium chloride $\left(\mathrm{CdCl}_{2} \mathrm{H}_{2} \mathrm{O}\right.$ pro analisi, Merck, Germany) for $96 \mathrm{~h}$ in a tank with a fish density of $34 \ell$ of water per fish. The tank was thermostatted at $20^{\circ} \mathrm{C}\left( \pm 0.2^{\circ} \mathrm{C}\right)$. Hard water, from dolomitic origin (Midgley et al., 1990) with a $\mathrm{pH}$ of 8.4 was obtained from municipal tap water pumped from the Mooi River. The tap water was treated for $2 \mathrm{~d}$ by vigorous aeration and by the substrate of the biological filter. Soft water with a $\mathrm{pH}$ of 7.51 was obtained from a borehole drilled into quartszite/shale contact ( $\mathrm{Nel}$, 1934) at the farm Rooipoort 29. Forty-eight hours before the fish were placed in the exposure tanks the water was aerated. Twelve hours before the fish were exposed to $\mathrm{Cd}$, the appropriate amount of $\mathrm{CdCl}_{2}$ was dissolved in the $1000 \ell$ exposure tanks to obtain 1 , 5,10 , and $20 \mathrm{mg} \mathrm{metal} \cdot \ell^{-1}$, respectively. Eighty-four hours after the fish were exposed, 12 to 15 specimens were caught and each fish placed into a respirometer with the water-tight lids removed. After $12 \mathrm{~h}$, the respirometers were gently closed under water and the $\mathrm{PO}_{2}$ values measured as described. The respirometers were suspended just below the water surfaces of the exposure tanks. The specific oxygen consumption rates of at least 10 specimens per $\mathrm{Cd}$ exposure were measured.

\section{Blood plasma and bile fluid analyses}

Blood samples $(0.3 \mathrm{~m} \ell)$ were collected by cardiac puncture and centrifuged at $9000 \mathrm{G}$ for $5 \mathrm{~min}$ to obtain blood plasma. Bile $(0.5 \mathrm{~m} \ell)$ was collected with a syringe from the gall bladder after 
TABLE 2

The concentration of $\mathrm{Cd}$ in the gill-lamellae and liver tissue after $\mathbf{9 6} \mathrm{h}$ exposure to different $\mathrm{Cd}$ concentrations in hard and soft water. For each exposure 10 fish were used. \pm : Standard deviation form the mean

\begin{tabular}{|c|c|c|c|c|c|c|c|}
\hline & \multicolumn{3}{|c|}{$\begin{array}{l}\text { Gills: control fish } \\
\left(\mu \mathrm{g} \cdot \mathrm{g}^{-1} \text { dry mass }\right)\end{array}$} & \multirow{2}{*}{$\begin{array}{c}\begin{array}{c}\text { Exposure } \\
\text { concen- } \\
\text { tration }\end{array} \\
\mathrm{Cd}\left(\mathrm{mg} \cdot \ell^{-1}\right)\end{array}$} & \multicolumn{3}{|c|}{$\begin{array}{l}\text { Gills: experimental fish } \\
\quad\left(\mu g^{\prime} \cdot g^{-1} \text { dry mass }\right)\end{array}$} \\
\hline & Range & Mean & \pm & & Range & Mean & \pm \\
\hline Hard water & $\begin{array}{c}4-59 \\
4-15 \\
4-15 \\
20-213\end{array}$ & $\begin{array}{c}28 \\
7 \\
7 \\
67\end{array}$ & $\begin{array}{c}18 \\
3 \\
3 \\
57\end{array}$ & $\begin{array}{c}1 \\
5 \\
10 \\
20\end{array}$ & $\begin{array}{c}14-326 \\
132-964 \\
686-3762 \\
570-3772\end{array}$ & $\begin{array}{c}116 \\
397 \\
2457 \\
1903\end{array}$ & $\begin{array}{c}114 \\
264 \\
1104 \\
1128\end{array}$ \\
\hline \multirow[t]{3}{*}{ Soft water } & $\begin{array}{l}38-163 \\
38-163 \\
28-280 \\
28-280\end{array}$ & $\begin{array}{c}87 \\
87 \\
146 \\
146\end{array}$ & $\begin{array}{l}38 \\
38 \\
90 \\
90\end{array}$ & $\begin{array}{c}1 \\
5 \\
10 \\
20\end{array}$ & $\begin{array}{c}31-171 \\
94-358 \\
113-439 \\
945-6371\end{array}$ & $\begin{array}{c}103 \\
212 \\
260 \\
3955\end{array}$ & $\begin{array}{c}37 \\
77 \\
99 \\
1778\end{array}$ \\
\hline & \multicolumn{3}{|c|}{$\begin{array}{l}\text { Liver: control fish } \\
\left(\mu g \cdot g^{-1} \text { dry mass }\right)\end{array}$} & $\begin{array}{l}\text { Exposure } \\
\text { concen- } \\
\text { tration }\end{array}$ & \multicolumn{3}{|c|}{$\begin{array}{l}\text { Liver: experimental fish } \\
\quad\left(\mu \mathrm{g} \cdot \mathrm{g}^{-1} \text { dry mass }\right)\end{array}$} \\
\hline & Range & Mean & \pm & $\mathrm{Cd}\left(\mathrm{mg} \cdot \ell^{-1}\right)$ & Range & Mean & \pm \\
\hline Hard water & $\begin{array}{l}1-56 \\
0-2 \\
0-2 \\
0-3\end{array}$ & $\begin{array}{c}10 \\
1 \\
1 \\
1\end{array}$ & $\begin{array}{c}17 \\
1 \\
1 \\
1\end{array}$ & $\begin{array}{c}1 \\
5 \\
10 \\
20\end{array}$ & $\begin{array}{c}2-46 \\
13-129 \\
14-130 \\
10-133\end{array}$ & $\begin{array}{l}13 \\
48 \\
61 \\
72\end{array}$ & $\begin{array}{l}14 \\
36 \\
38 \\
50\end{array}$ \\
\hline Soft water & $\begin{array}{l}1-6 \\
1-6 \\
1-7 \\
1-7\end{array}$ & $\begin{array}{l}3 \\
3 \\
4 \\
4\end{array}$ & $\begin{array}{l}2 \\
2 \\
2 \\
2\end{array}$ & $\begin{array}{c}1 \\
5 \\
10 \\
20\end{array}$ & $\begin{array}{c}18-134 \\
68-321 \\
105-251 \\
65-724\end{array}$ & $\begin{array}{c}52 \\
179 \\
160 \\
219\end{array}$ & $\begin{array}{c}43 \\
101 \\
50 \\
210\end{array}$ \\
\hline
\end{tabular}

opening of the abdominal cavity.

After the $\mathrm{MO}_{2}$ measurements, dissolved solids in blood plasma and bile fluid were measured using a refractometer (Model T/C 10402, American Optical Company). Chlorides in the blood plasma were determined using a chloride titrator (Clinical Model 4-4495, American Instrument Company).

\section{$\mathrm{MO}_{2}$ calculations and mass-specific oxygen consumption}

To calculate $\dot{\mathrm{M}} \mathrm{O}_{2}$ the obtained $\Delta \mathrm{PO}_{2}$ values were first multiplied by the molar solubility coefficient for oxygen (Green and Carrit, 1967; Cameron, 1986) at $20^{\circ} \mathrm{C}$, followed by the calculations

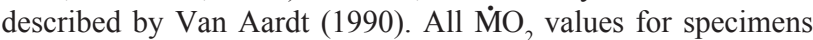
ranging from $15 \mathrm{~g}$ to $125 \mathrm{~g}$ were corrected to be equivalent to the specific oxygen consumption rate of a live body mass of a $30 \mathrm{~g}$ T. sparrmanii. This was obtained by measuring the specific oxygen consumption rates of 30 specimens ranging from 13 to $131 \mathrm{~g}$ bodymass. The data were plotted on a graph with $\dot{\mathrm{M}} \mathrm{O}_{2}$ at the y-axis on a linear scale and the live body mass on a logarithmic scale. From the data a straight line on the graph could be calculated.

\section{Effects of handling stress on $\mathrm{MO}_{2}$}

To determine the effect of handling stress on the resting metabolic rate of the banded tilapia, ten specimens were taken from the holding tanks by netting and each placed in a respirometer suspended in the $1000 \ell$ temperature controlled tank. The $\dot{\mathrm{MO}}$, was measured immediately after handling as described above. In the same manner individual $\dot{\mathrm{MO}}$, was measured in other groups of ten T. sparrmanii, 2, 4, 8, 10 and $13 \mathrm{~h}$ after they had been handled (Wedemeyer, 1976).

\section{Oxygen consumption by bacteria and other organisms}

The $\dot{\mathrm{MO}}_{2}$ in the holding fish tank water was measured in clean respirometers without fish for $2 \mathrm{~h}$.

\section{$\mathrm{Cd}$ analysis of the different hard water types}

The applied Cd concentrations were determined in the exposure tanks in Fish tank hard water, Rooipoort soft water and the 3 reconstituted freshwater types (Rand et al., 1995), $96 \mathrm{~h}$ after the $\mathrm{CdCl}_{2} \cdot \mathrm{H}_{2} \mathrm{O}$ was dissolved. The water samples were taken from the exposure tanks and from the three reconstituted fresh water types while the water was vigorously agitated by means of aeration stones. Cd was extracted from the water samples with tetrachlorometane using Kit No 13 from Macherey-Nagel, Germany and analysed spectrophotometrically for cadmium (accuracy $\left.0.002 \mathrm{mg} \mathrm{Cd} \cdot \ell^{-1}\right)$

\section{Cd analysis of gill and liver tissue}

After the $96 \mathrm{~h}$ exposure period to $\mathrm{Cd}$ the gill tissue on the branchial arch and also liver tissue was cut from freshly dissected fish and the wet mass per fish determined. From a previous experiment the dry mass at $60^{\circ} \mathrm{C}$ was determined after $24 \mathrm{~h}$ drying in the oven. For T. sparrmanii dried gill tissue mass was $17.6 \%$ of the wet gill tissue mass and liver tissue $29.9 \%$. To analyse the wet tissue it was first digested with $4 \mathrm{~m} \ell \mathrm{HNO} 3$ (pro-analisi, Merck, Germany 0.000001 $\% \mathrm{Cd}$ ) at $70^{\circ} \mathrm{C}$ for $12 \mathrm{~h}$. The digested samples were diluted to a volume of $10 \mathrm{~m} \ell$ with de-ionised water. One hundred $\mu \ell$ of sample was diluted 20 times and used to determine $\mathrm{Cd}$ with a Varian Spectra 250 Plus and a GTA95 electrothermal oven (Varian, Australia). Palladium and Triton X-100, as modifiers, were used. Accuracy better than $5 \mu \mathrm{g} \mathrm{Cd} \cdot \ell^{-1}$ was achieved. However, a straight regression line through the standards could not be achieved. The analysis was expressed per gram of dry tissue. The certified reference material used was obtained as dogfish reference material (National Research Council, Canada) and used to determine analytical efficiency.

\section{Statistical analysis}

A statistical package was used to compare control with experimental data using one-way analyses of variance [ANOVA and Tukey's 
Figure 2

The effect of handling stress on the specific oxygen consumption rate $\left(\dot{M} \mathrm{O}_{2}\right)$ of Tilapia sparrmanii. Each point on the graph represent ten fish. The vertical bars represents the standard deviation from the mean.

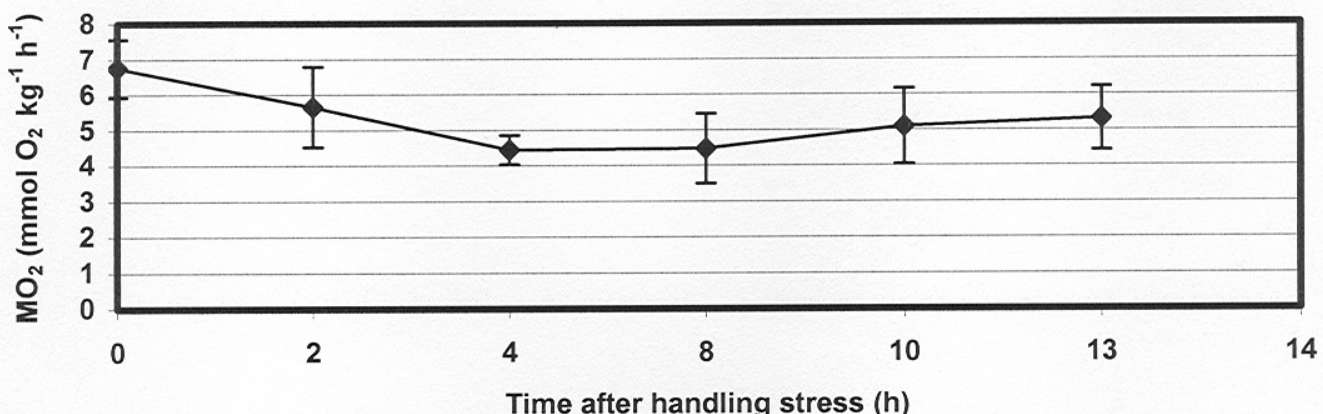

post hoc test for multiple comparisons of significant different means $(\mathrm{P}<0.05)]$

Data are presented as means $( \pm=$ standard deviation from the mean).

\section{Results}

\section{Complexation of $\mathrm{Cd}$ in different hard water types}

The concentrations of cadmium dissolved in Mooi River water, reconstituted freshwater, Rooipoort soft water, precipitate from solution after $96 \mathrm{~h}$ (Table 1). For hard water less than $1 \%$ of cadmium could be analysed from water samples taken during vigorous aeration. It was observed that within minutes of the application of $\mathrm{CdCl}_{2}$ in the water, precipitation occurred, presumably as cadmium sulphate (Fridberg et al., 1979). According to Bodek et al. (1988) the solubility product constants for $\mathrm{Cd}$ are such that total precipitation in hard and soft water is possible.

\section{$\mathrm{Cd}$ accumulation in gill lamelae and liver tissue}

Fish exposed to 1 and $5 \mathrm{mg} \cdot \ell^{-1}$ cadmium, for both hard and soft water, accumulate about ten times less in their gill tissue compared to 10 and $20 \mathrm{mg} \cdot \ell^{-1}$ cadmium exposure (Table 2 ). The $\mathrm{Cd}$ accumulation in the liver is nearly twenty times less compared with gill tissue and is found in the liver when fish are exposed to both hard and soft water. The differences, however, are not significant.

\section{Oxygen consumption rate of the water medium}

Metabolic activity in the respirometer water, probably caused by bacterial or algal consumption of oxygen, does not change the $\mathrm{PO}_{2}$ by more than $3 \mathrm{~mm} \mathrm{Hg}$ during the $2 \mathrm{~h}$ measurement period for both the respirometers in hard water. In soft water no changes in the partial pressure of oxygen were found.

\section{Oxygen consumption rate and fish size}

For the 30 fish measured the $\dot{\mathrm{MO}}$, values fell on a regression line represented by the equation, $\mathrm{Y}=-3.3523 \mathrm{X}+10.06$. The slope $(-3.3523)$ was used to derive the correction factor for $\dot{\mathrm{M}}_{2}$ of fish ranging between $15 \mathrm{~g}$ and $140 \mathrm{~g}$ to a $30 \mathrm{~g}$ standard banded tilapia.

\section{$\dot{\mathrm{MO}}_{2}$ and handling stress}

Handling stress resulted in a $37 \%$ increase of the specific $\mathbf{M O}_{2}$ to $6.7 \mathrm{mmol} \mathrm{O} \cdot \mathrm{kg}^{-1}$ fish $\cdot \mathrm{h}^{-1}$ (Fig.2). The differences are statistically significant $(\mathrm{P}<0.05)$. The value of $4.5 \mathrm{mmol} \mathrm{O} \cdot \mathrm{kg}^{-1} \mathrm{fish} \cdot \mathrm{h}^{-1}, 4 \mathrm{~h}$ after handling, was not significantly different 8,10 , or $13 \mathrm{~h}$ after the fish had been handled. From these findings it was decided that experimental fish would be kept in the open respirometers sub-

\section{aControl hw Experiment hw Control sw Experiment sw}

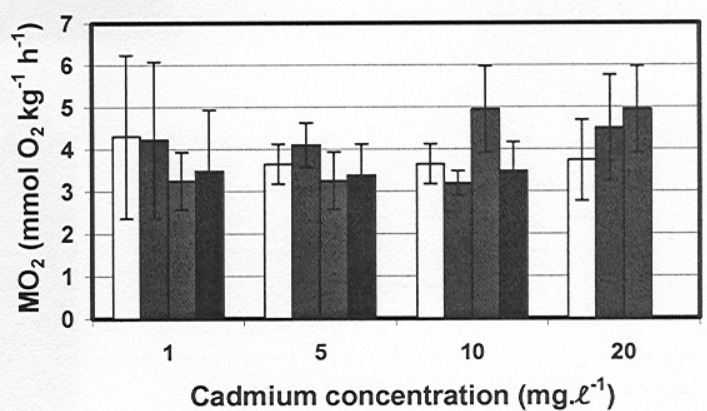

Figure 3

The effect of different $C d$ concentrations on the specific oxygen consumption rate $\left(\mathrm{MO}_{2}\right)$ of Tilapia sparrmanii measured in hard water ( $h w$ ) and soft water (sw). All fish died before $96 \mathrm{~h}$ exposure to $20 \mathrm{mg} \mathrm{Cd} \cdot \ell^{-1}$ in soft water. The vertical bars represent the standard deviation from the mean.

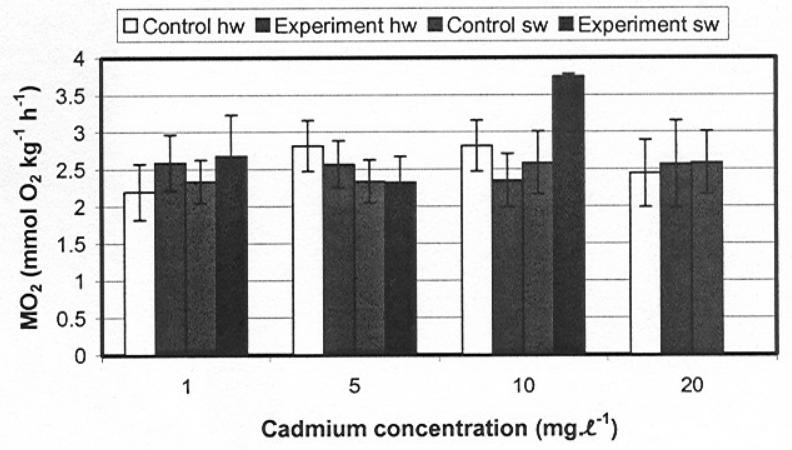

Figure 4

The effect of different Cd concentrations on the specific oxygen consumption rate $\left(\mathrm{MO}_{2}\right)$ of Tilapia sparrmanii measured in hard (hw) and soft water (sw) exposed for $96 \mathrm{~h}$ to $\mathrm{Cd}$. The $\mathrm{MO}_{2}$ was measured at $94 \mathrm{~h}$ with fish kept at progressively hypoxic conditions $(130 \mathrm{~mm} \mathrm{Hg}$ to $10 \mathrm{~mm} \mathrm{Hg})$ for $2 \mathrm{~h}$. All fish died at $20 \mathrm{mg} \mathrm{Cd} \cdot \ell^{-1}$ exposure to soft water. The vertical bars represent the standard deviation from the mean.

merged in the exposure tanks for at least $10 \mathrm{~h}$ before resting specific $\dot{\mathrm{MO}} 2$ measurements were made.

\section{Effects of hard water on the $\dot{M O}_{2}$ for Cd exposed fish}

No effects of $1,5,10$ and $20 \mathrm{mg} \mathrm{Cd} \cdot \ell^{-1}$ hard water on the $\mathrm{MO}_{2}$ were found when compared with values from control fish (3.2 and 4.5 mmol $\mathrm{O}_{2} \cdot \ell^{-1}$, Fig. 3 ). The mean oxygen consumption rates were between 3.55 and $4.37 \mathrm{mmol} \mathrm{O} \cdot \mathrm{kg}^{-1} \cdot \mathrm{h}^{-1}$. 
TABLE 3

Blood chloride concentration and dissolved solids in bile and blood plasma after $96 \mathrm{~h}$ exposure to different $\mathrm{Cd}$ concentrations in hard and soft water. For each exposure 10 fish were used. \pm : Standard deviation.

\begin{tabular}{|c|c|c|c|c|c|c|c|}
\hline & \multicolumn{3}{|c|}{$\begin{array}{l}\text { Blood plasma chlorides: } \\
\text { control fish (mmol } \mathrm{NaCl})\end{array}$} & \multirow{2}{*}{$\begin{array}{l}\text { Exposure } \\
\text { concentr. }\end{array}$} & \multicolumn{3}{|c|}{$\begin{array}{l}\text { Blood plasma chlorides: } \\
\text { exp. fish (mmol } \mathrm{NaCl})\end{array}$} \\
\hline & Range & Mean & \pm & & Range & Mean & \pm \\
\hline Hard water & $\begin{array}{l}138-152 \\
139-164 \\
139-164 \\
112-136\end{array}$ & $\begin{array}{l}144 \\
149 \\
149 \\
128\end{array}$ & $\begin{array}{l}4 \\
8 \\
8 \\
7\end{array}$ & $\begin{array}{c}1 \\
5 \\
10 \\
20\end{array}$ & $\begin{array}{l}133-147 \\
134-157 \\
139-155 \\
121-150\end{array}$ & $\begin{array}{l}141 \\
143 \\
147 \\
133\end{array}$ & $\begin{array}{l}4 \\
8 \\
5 \\
8\end{array}$ \\
\hline \multirow[t]{3}{*}{ Soft water } & $\begin{array}{c}122-147 \\
122-147 \\
98-134 \\
98-134\end{array}$ & $\begin{array}{l}137 \\
137 \\
122 \\
122\end{array}$ & $\begin{array}{c}8 \\
8 \\
10 \\
10\end{array}$ & $\begin{array}{c}1 \\
5 \\
10 \\
20\end{array}$ & $\begin{array}{c}134-158 \\
106-129 \\
85-137 \\
32-90\end{array}$ & $\begin{array}{c}150 \\
114 \\
108 \\
58\end{array}$ & $\begin{array}{c}8 \\
17 \\
16 \\
17\end{array}$ \\
\hline & \multicolumn{3}{|c|}{$\begin{array}{l}\text { Dissolved solids in plasma: } \\
\text { control fish }\left(\mathrm{g} \cdot 100 \mathrm{ml}^{-1}\right)\end{array}$} & $\begin{array}{l}\text { Exposure } \\
\text { concentr. }\end{array}$ & \multicolumn{3}{|c|}{$\begin{array}{l}\text { Dissolved solids in plasma: } \\
\text { experimental fish }\left(\mathrm{g} \cdot 100 \mathrm{~m} \ell^{-1}\right)\end{array}$} \\
\hline & Range & Mean & \pm & $\mathrm{Cd}\left(\mathrm{mg} \cdot \ell^{-1}\right)$ & Range & Mean & \pm \\
\hline Hard water & $\begin{array}{l}5-6 \\
4-6 \\
4-6 \\
5-6\end{array}$ & $\begin{array}{l}5 \\
5 \\
5 \\
5\end{array}$ & $\begin{array}{l}0.4 \\
0.7 \\
0.7 \\
0.4\end{array}$ & $\begin{array}{c}1 \\
5 \\
10 \\
20\end{array}$ & $\begin{array}{l}5-6 \\
5-7 \\
4-6 \\
5-8\end{array}$ & $\begin{array}{l}5 \\
6 \\
5 \\
6\end{array}$ & $\begin{array}{c}0.4 \\
0.5 \\
0.6 \\
1\end{array}$ \\
\hline \multirow[t]{3}{*}{ Soft water } & $\begin{array}{l}5-7 \\
5-7 \\
5-6 \\
5-6\end{array}$ & $\begin{array}{l}6 \\
6 \\
5 \\
5\end{array}$ & $\begin{array}{l}0.5 \\
0.5 \\
0.3 \\
0.3\end{array}$ & $\begin{array}{c}1 \\
5 \\
10 \\
20\end{array}$ & $\begin{array}{l}4-7 \\
6-7 \\
6-8 \\
6-9\end{array}$ & $\begin{array}{l}6 \\
7 \\
6 \\
7\end{array}$ & $\begin{array}{c}1 \\
2 \\
0.7 \\
1\end{array}$ \\
\hline & \multicolumn{3}{|c|}{$\begin{array}{l}\text { Dissolved solids in bile: } \\
\text { control fish }\left(\mathrm{g} \cdot 100 \mathrm{ml}^{-1}\right)\end{array}$} & $\begin{array}{l}\text { Exposure } \\
\text { concentr. }\end{array}$ & \multicolumn{3}{|c|}{$\begin{array}{l}\text { Dissolved solids in bile: } \\
\text { experimental fish }\left(\mathrm{g} \cdot 100 \mathrm{~m}^{-1}\right)\end{array}$} \\
\hline & Range & Mean & \pm & $\mathrm{Cd}\left(\mathrm{mg} \cdot \ell^{-1}\right)$ & Range & Mean & \pm \\
\hline Hard water & $\begin{array}{l}15-17 \\
15-16 \\
15-16 \\
14-16\end{array}$ & $\begin{array}{l}16 \\
16 \\
16 \\
16\end{array}$ & $\begin{array}{l}0.5 \\
0.3 \\
0.3 \\
0.5\end{array}$ & $\begin{array}{c}1 \\
5 \\
10 \\
20\end{array}$ & $\begin{array}{l}15-16 \\
15-17 \\
16-17 \\
15-17\end{array}$ & $\begin{array}{l}16 \\
16 \\
16 \\
15\end{array}$ & $\begin{array}{l}0.3 \\
0.5 \\
0.2 \\
0.6\end{array}$ \\
\hline Soft water & $\begin{array}{l}14-16 \\
14-16 \\
14-15 \\
14-15\end{array}$ & $\begin{array}{l}16 \\
16 \\
15 \\
15\end{array}$ & $\begin{array}{l}0.7 \\
0.7 \\
0.5 \\
0.5\end{array}$ & $\begin{array}{c}1 \\
5 \\
10 \\
20\end{array}$ & $\begin{array}{c}14-16 \\
14-16 \\
12-14 \\
8-12\end{array}$ & $\begin{array}{l}16 \\
16 \\
13 \\
11\end{array}$ & $\begin{array}{l}0.5 \\
0.2 \\
0.6 \\
1.3\end{array}$ \\
\hline
\end{tabular}

Effects of soft water ( $\mathrm{pH}$ 8.4) on the $\mathrm{MO}_{2}$ for cadmium exposed fish

During the $96 \mathrm{~h}$ exposure period to $\mathrm{Cd}$ in soft water the oxygen consumption rate for control and experimental fish stayed the same except for the $20 \mathrm{mg}$ Cd concentration, where all the experimental fish died before the $96 \mathrm{~h}$ exposure period expired (Fig.3).

\section{Effects of hypoxic water on the $\dot{M O}_{2}$ for Cd exposed fish}

\section{a) Hard water}

The $\dot{\mathrm{MO}}_{2}$ was between 2.41 and $2.80 \mathrm{mmol} \mathrm{O} \cdot \mathrm{kg}^{-1}$ fish $\cdot \mathrm{h}^{-1}$ and is not significant between control and experimental fish in hard water. This value is $34 \%$ less compared with $\dot{\mathrm{MO}}$ of fish in normoxic hard water (Fig.4).

\section{b) Soft water}

For experimental fish exposed to $10 \mathrm{mg} \mathrm{Cd}$, the $\mathrm{MO}_{2}$ increased to $3.7 \mathrm{mmol} \mathrm{O} \cdot \mathrm{kg}^{-1}$ fish $\mathrm{h}^{-1}$. This is significantly above the $10 \mathrm{mg} \cdot \ell^{-1}$ normoxic $\mathrm{Cd}$ exposure control values of between 2.3 and $2.6 \mathrm{mmol}$ $\mathrm{O}_{2} \cdot \mathrm{kg} \cdot \mathrm{h}^{-1}$. All fish died at $20 \mathrm{mg} \cdot \ell^{-1}$ $\mathrm{Cd}$, both in normoxic and progressive hypoxic water conditions. The oxygen consumption rates for hypoxic fish are $35 \%$ less compared with $\dot{\mathrm{MO}}{ }_{2}$ of fish in normoxic (130 $\mathrm{mm} \mathrm{Hg}$ ) soft water (Fig. 4) for all other exposure concentrations.

Blood plasma chlorides decrease significantly from $122 \mathrm{mmol} \mathrm{NaCl}$ to $108 \mathrm{mmol}$ for $10 \mathrm{mg} \mathrm{Cd} \cdot \ell^{-1}$ and to $58 \mathrm{mmol} \mathrm{NaCl}$ for $20 \mathrm{mg} \mathrm{Cd} \cdot \ell^{-1}$ exposed fish compared with a value of $122 \mathrm{mmol} \mathrm{NaCl}$ for the controls. Dissolved solids in bile for the 10 and $20 \mathrm{mg} \cdot \ell^{-1} \mathrm{Cd}$ concentrations also decreases significantly compared with the control values. However, dissolved solids in blood plasma stays the same for both experimental and control fish for all $\mathrm{Cd}$ exposed concentrations.

\section{Discussion}

In seawater and estuarine conditions, $\mathrm{Cd}$ complexation is caused by chloride as ligand (Sunda et al., 1978) but in Mooi River hard water the carbonate and phosphate ions are probably the major complexation ligands and not chlorides. This is so because, as shown in results from Table 1 , in reconstituted hard water with low chloride concentration, $\mathrm{Cd}$ complexation still takes place.

From these experiments it is not clear whether $T$. sparrmanii are resistant to $\mathrm{Cd}$ toxicity. It appears that the differences in toxic responses are probably related to the bioavailable fraction of the administered dose being very low at hard water conditions. At exposure levels in soft water, with $23 \%$ of $\mathrm{Cd}$ in solution (after speciation) and bioavailable, the metal concentration is about ten times higher compared to $\mathrm{Cd}$ exposed to the grass shrimp and other aquatic animals (Sunda et al., 1978). At these concentrations no deaths were experienced for T. sparrmanii.

Compared to other heavy metals such as $\mathrm{Pb}, \mathrm{Zn}$ and $\mathrm{Cu}, \mathrm{Cd}$ toxicity is much more influenced by water hardness. The $48 \mathrm{~h} \mathrm{LC}_{50}$ for rainbow trout is below $0.1 \mathrm{mg} \mathrm{Cd} \cdot \ell^{-1}$ for water hardness of $20 \mathrm{mg} \cdot \ell^{-1} \mathrm{CaCO}_{3}$ but toxicity (using $5 \mathrm{mg} \mathrm{Cd} \cdot \ell^{-1}$ ) decreases about 50 -fold in hard water with a hardness of $250 \mathrm{mg} \cdot \ell^{-1}$ as $\mathrm{CaCO}_{3}$ 
(Brown, 1968). However, banded tilapia are more resistant to $\mathrm{Cd}$ toxicity compared to trout, because at $10 \mathrm{mg} \mathrm{Cd}$ all specimens were still alive after $96 \mathrm{~h}$ exposure at the same hardness level.

The toxicity tests done with $\mathrm{Cd}$ on the $\mathrm{MO}_{2}$ reveal an unanticipated variation of the $\mathrm{MO}_{2}$ values. Only a small part of this variation could be ascribed to variation in the individual specimens tested. This variation phenomenon was also discussed by Rand et al., (1995) who mention that for $\mathrm{LC}_{50}$ values it is the "result of unrecognised changes in the organisms or in the test conditions". The same set of parameters in the same laboratory for a particular experiment done on hard water using trout, show remarkably different $\mathrm{LC}_{50}$ results. This was also found for inter-laboratory experiments using the same experimental conditions (Rand et al., 1995; Sprague, 1995; Mount, 1966).

In these experiments we suggest that the variation in $\dot{\mathrm{MO}}_{2}$ found in all the exposure experiments can be the result of the physical nature of the precipitated Cd complexes. The Cd complex is mechanically brought into suspension by vigorous aeration. In this manner varied $\mathrm{Cd}$ deposits on the gill surfaces could be the result, especially for fish that stay and swim deeper in the exposure tanks. The deposits, in turn, cause damage to the gill epithelium that differs from fish to fish, resulting in variations in the $\dot{\mathrm{MO}}{ }_{2}$ values. Even though Cd precipitates as a metal complex on the external gill surface there is a likelihood that the lower $\mathrm{pH}$ at the gill microenvironment could result in uptake of $\mathrm{Cd}$ thereby increasing bioavailability. In this regard a mechanism how positive metal compounds react with low $\mathrm{pH}$ gill epithelial constituents was put forward by Reid and Macdonald (1991). This mechanism could be substantiated by the fact that bioaccumulation of Cd in or on the gill tissue, with large variation in concentration, was demonstrated in our experiments.

Analysis of cadmium in hard water, $96 \mathrm{~h}$ after it was dissolved showed that this metal completely precipitates out when dissolved in hard water. This is also true for relatively soft water from the Rooipoort farm. Precipitation of Cd is in accord with the very low solubility characteristics described for Cd (Rand et al., 1995). Despite the low solubility of the Cd-complexation compound, biological effects of its toxicity can be detected, starting at $10 \mathrm{mg}$ $\mathrm{Cd} \cdot \ell^{-1}$ soft alkaline water. This finding should be evaluated with the knowledge that the precipitate is deposited on the gill epithelium, damaging the gill structure that leads to changes in its respiratory function.

The fact that bile-dissolved solids and chloride plasma levels in T. sparrmanii are decreased and blood plasma solids increased during $\mathrm{Cd}$ exposure, suggests that the effects of $\mathrm{Cd}$ on the gill epithelium are not only the result of gill epithelium damage but that the metal toxicity mechanism, via gill uptake, has its effects on the whole physiology of the fish, including a rise in the $\mathrm{MO}_{2}$, This is substantiated by the finding that a sharp increase in the accumulation of $\mathrm{Cd}$, both in gill and liver tissue was established in our experiments. Cd bioaccumulation would increase in the softer water due to the greater bioavailibility. However, since the bioavailability of $\mathrm{Cd}$ is $<1 \%$ in the hard water the mechanism of toxicity has to be associated with the precipitation of Cd complexes on the gill surface rather than uptake-based toxicity. This view is not shared by Playle et al., (1993) who showed that Cd strongly binds to fat head minnow gills. They reasoned that the uptake of $\mathrm{Cd}$ takes place through high affinity Ca channels, in addition to surface binding. The decreased plasma $\mathrm{Cl}$ observed in our experiments could be an indication of altered acid-base balance with more $\mathrm{CO}_{2}$ being buffered in the red blood cells, due to the increased diffusion distance, resulting in the production of $\mathrm{HCO}_{3}$. This would result in $\mathrm{Cl}$ ions being shifted from the plasma into the erytrocytes to maintain electroneutrality. Increase of plasma solids could in turn be related to compensatory mechanisms initiated to maintain plasma osmolality (Wilson and Taylor, 1993).

It is known that the highest Cd accumulation in vertebrates' organs occurs in kidneys. Unfortunately in $T$. sparrmanii, the collection of tissue from the small and elongated kidney for analysis was unpractical and prone to cross-contamination with blood. Undoubtedly the liver is involved in the collection and detoxification of $\mathrm{Cd}$ by $\mathrm{Cd}$-metallothionein formation, as was proven for kidneys by Van der Malie and Garvey (1979).

The decrease in the $\mathrm{MO}_{2}$ during progressive hypoxia in closedoff respirometers indicates that when these measurements are done in closed-off respirometers, $\mathrm{PO}_{2}$ readings should be done before the critical $\mathrm{PO}_{2}$ tension of the water is reached (Herreid, 1980). In practice, for fish, the oxygen tension in the water should not decrease more than $20 \%$ compared to the starting $\mathrm{PO}_{2}$. The high $\mathrm{MO}_{2}$ found for hypoxic treated tilapia is reflected by an increase in the gill frequency, a physiological parameter not measured in these experiments but was observed in both the large mouth bass (Micropteris salmoides) and the mud fish (Labeo capensis) during progressive hypoxia (personal observations).

It is recommended that before the toxic effect of a heavy metal is tested, its solubility and complexation properties at different $\mathrm{pH}$ values, together with its toxicity in hard and soft water, should be studied and evaluated.

It can be stated that $\mathrm{Cd}$, released through mining activities (Wittman and Förstner, 1977), in the Mooi River catchment area can be precipitated by hard water from dolomitic origin. These insoluble metal complexes can, after precipitation, be stored in the river sediments of the Mooi River and the river's three dams. Any future change in the solubility of the precipitated metals, such as a dramatic and sudden decrease in the $\mathrm{pH}$ of the water and physical disturbance of the sediment, could potentially release these toxic metals in a soluble form into the water. Therefore, future measurements of metal accumulation in the sediments of the Mooi River are important to assess the potential dangers of toxic metals in this area as a whole.

\section{Acknowledgements}

We wish to thank the Research Focus Area: Environmental Sciences and Management, for financial assistance and the School of Environmental Sciences and Development, Potchefstroom University for CHE, Potchefstroom, South Africa, for providing the research facilities.

\section{References}

ANDERSON PD and D'APOLLINA S (1978) Aquatic animals. In: Butler GC (ed.) Principles of Ecotoxicology. John Wiley and Sons, New York.

ANDERSON D and CONNING DM (1993) Experimental Toxicology. The Basic Issues. The Royal Society of Chemistry, Cambridge University Press, Cambridge, UK.

BODEK L, LYMAN WJ, REEHL WF and ROSENBLATT D H (1988) Environmental Inorganic Chemistry: Properties, Processes, and Estimation Methods. New York, Pergamon.

BRIDGES CR. and BUTLER PJ (1989) Techniques in Comparative Respiratory Physiology. Cambridge University Press, Cambridge.

BROWN VM (1968) The calculation of the acute toxicity of mixtures of poisons to rainbow trout. Water Res. 2 723-733.

BURTON DT, JONES AH and CAIRNS J (1972) Acute zinc toxicity to rainbow trout (Salmo gairdneri): confirmation of the hypothesis that death is related to tissue hypoxia. J. Fish. Res. Bd. Can. 29 1463-1466.

BUTLER GC (1978) Principles of Ecotoxicology. Scope 12. John Wiley \& Sons, New York. 
CAMERON JN (1986) Principles of Physiological Measurement. Academic Press, New York.

CARPENÉ E, CATANI O, SERRAZANETTI GP, FEDRIZZI G and CORTESI P (1990) Zinc and copper in fish from natural waters and rearing ponds in Northern Italy. J. Fish Biol. 37 293-299.

DEPLEDGE MH (1990) New approaches in ecotoxicology: Can interindividual physiological variability be used as a tool to investigate pollution effects? Ambio 19 251-252.

FELTS PA and HEATH AG (1984) Interactions of temperature and sublethal environmental copper exposure on the energy metabolism of blue gill, Lepomis macrochiris Rafinesque. J. Fish Biol. 25 445-453.

FRIBERG L, KJELLSTRÖM T, NORDBERG G and PISCATOR M (1979) Cadmium. In: Friberg L, Nordberg GF and Vouk VB (eds.) Handbook on the Toxicology of Metals. Elsevier, Amsterdam. 355-410.

GOSS GG and WOOD CM (1988) The effects of acid and acid/alumimium exposure in circulating plasma cortisol levels and other blood parameters in the rainbow trout Salmo gairdneri. J. Fish Biol. 32 63-76.

GREEN EJ and CARRIT DE (1967) New tables for oxygen saturation of sea water. J. Mar. Res. 25 140-147.

HEATH AG (1984) Changes in tissue adenylates and water content of blue gill, Lepomis macrochirus exposed to copper. J. Fish. BioI. 24299 309.

HEATH AG (1987) Water Pollution and Fish Physiology. CRC Press, Boca Raton, Florida, USA.

HERREID CF (1980) Hypoxia in invertebrates. Comp. Biochem. Physiol. 67A $311-320$

HITCHMAN ML (1983) Calibration and accuracy of polarographic oxygen sensors. In: Gnaiger E and Forster H (eds.) Polarographic Oxygen Sensors. Aquatic and Physiological Applications. Springer-Verlag, Berlin, pp.19-30.

KELLY M (1988) Mining and the Freshwater Environment. Elsevier Applied Sciences, London.

KOTRLY S and SUCHA L (1985) Handbook of Equilibria in Analytical Chemistry. Chichester, UK. Ellis Horwood.

KLERKS PL and LEVINTON JS (1989) Effects of heavy metals in a polluted aquatic ecosystem. In: SA Levin, MA Harwell, JR Kelly and KD Kimball (eds.) Ecotoxicology: Problems and Approaches. Springer-Verlag, New York.

LLOYD R (1961a) Effect of dissolved oxygen concentrations on the toxicity of several poisons to rainbow trout (Salmo gairdnerii Richardson). J. Exp. Biol. 38 447-455.

MALLATT J (1985) Fish gill structural changes induced by toxicants and other irritans: A statistical review. Can. J. Fish. Aquat. Sci. 42 630648.

MIDGLEY DC, PITMAN WV and MIDDELTON BJ (1990) Surface water resources of South Africa, Book of maps. Volume II, Drainage Region C Vaal. WRC Report no 298/2.2/94. Map no. 03 and 6.2. Pretoria: Government Printer.

MOUNT D I (1966) The effect of total hardness and $\mathrm{pH}$ on acute toxicity of zinc to fish. Int. J. of Air and Water Poll. 10 49-56.

NEL LT (1934) Geological Map of Klerksdorp-Ventersdorp. Sheet 1, and sheet 2. Geological Survey, Pretoria: Government Printer.

NRIAGU JO and PACYNA JM (1988) Quantitative assessment of worldwide contamination of air, water and soils by trace metals. Nature 333 134-139.

PELGROM SM, GJLAMERS LPM, HAAIJMAN A, BALM PHM, LOCK RAC and WENDELAAR-BONGA SE (1994) Interactions between copper and cadmium during single or combined metal exposures in the teleost fish Oreochromis mossambicus: Heavy metal accumulation and endocrine events. In: Muller R and Loyd R (eds.) Sub-Lethal and Chronic Effects of Pollutants on Freshwater Fish. University Press Cambridge, Cambridge, pp 62-74.

PLAYLE RC, DIXON DG and BURNISON, K (1993) Copper and cadmium binding to fish gills: Modification by dissolved organic carbon and synthetic ligands. Can. J. Fish. Aquat. Sci. 50 2667-2677.

RAND GM, WELLS PG, McCARTHY LS and RAND GM (1995) Introduction to aquatic toxicology. In: GM Rand (ed.) Fundamentals of Aquatic Toxicology: Effects, Environmental Fate, and Risk Assessment. Taylor and Francis, Washington, DC. 3-67.

REID SD and MACDONALD DG (1991) Metal binding activity of the gills of the rainbow trout (Onchorhynchus mykiss). Can. J. Fish. Aquat. Sci. 48 1061-1068.

SCHRECK C B and LORZ H W (1978) Stress response of Choho Salmon (Oncorhynchus kisutch) elicited by cadmium and copper and potential use of cortisol as an indicator stress. J. Fish. Res. Bd. Can. $351124-$ 1129.

SEVERINGHAUSE J W and BRADLEY BA (1971) Blood gas electrodes or what the instructions didn't say. Radiometer, Copenhagen ST 59. 1-64.

SKELTON P (1993) A Complete Guide to the Freshwater Fishes of Southern Africa. Southern Books, Johannesburg.

SPRAGUE JB (1995) Appendix C: Factors that modify toxicity. In: Rand GM (ed.) Fundamentals of Aquatic Toxicology. Effects, Environmental Fate, and Risk Assessment Taylor and Francis, Washington DC. 1012-1051.

SUNDA WG, ENGEL DW and THUOTTE RM (1978) Effect of chemical speciation on toxicity of cadmium to grass shrimp, Palaemonetes pugio: Importance of free cadmium ion. Environ. Sci. Tech. 12 409-413.

TRUHAUT T (1974) Ecotoxicology- a new branch of toxicology: General survey of its aims, methods and prospects. Proc. NATO Science Committee Conference on Ecotoxicology. Held at Mt. Gabriel, Quebec, Canada, May 6-10, 1974. Plenum Press, New York.

VAN AARDT WJ (1990) Respirometrie - soos toegepas op terrestriële en akwatiese invertebrate. SA Tydskrif vir Natuurwet. en Tegnol. 9 149-161.

VAN AARDT WJ and FREY BJ (1979) 0xygen consumption and responses of the freshwater snail Bulinus (Physopsis) globosus to gradients of different oxygen tensions. SA J. Zool. 14 202-207.

VANDER MALIE RJ and GARVEY JS (1979) Radioimmunoassay of metallothioneins. J. Biol. Chem. 254 8416-8421.

WALSH AH (1984) Biology and diseases of fish. In: Fox JG (ed.) Laboratory Animal Medicine. Academic Press, London. 477-541.

WEDEMEYER G (1976) Physiological response of juvenile coho salmon (Oncorhynchus kisutch) and steelhead trout (Salmo gairdneri) to handling and crowding stress in intensive fish culture. J. Fish. Res. Bd. Can. 33 2699-2702.

WENDELAAR-BONGA SE (1997) The stress response in fish. Physiol. Reviews 77 591-625.

WILSON RW and TAYLOR EW (1993) The physiological responses of freshwater rainbow trout, Oncorhynchus mykiss, during acutely lethal copper exposure. J.Comp.Physiol. 163 38-47.

WITTMANN GTW and FÖRSTNER U (1977) Heavy metal enrichment in mine drainage. III, The Klerksdorp, West Wits and Evander Goldfields. SA J. Sci. 73 53-57.

ZITKO V and CARSON WG (1976) A mechanism of the effects of water hardness on the lethality of heavy metals to fish. Chemosphere $\mathbf{5}$ 299-303. 